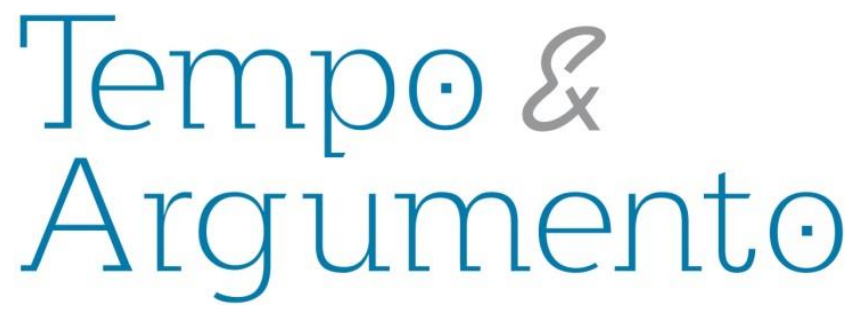

\title{
Experiências primárias e descontinuidades da recordação: notas a partir de um texto de Reinhart Koselleck ${ }^{1}$
}

\begin{abstract}
Resumo
Este artigo tem como ponto de partida um texto de Reinhart Koselleck sobre o tema da memória, que analisa supostas descontinuidades entre as experiências primárias e as formas secundárias de recordação. Embora seja um texto específico e não se pretenda compreender as afirmações nele contidas como fundamentos de um suposto pensamento do autor em sua unidade, são indicadas algumas possíveis relações com teses presentes em outras de suas obras. Em seguida, algumas de suas formulações são trazidas para o plano mais estritamente epistemológico e confrontadas com teses de autores como Aleida Assmann, Joël Candau, Hannah Arendt e Paul Ricoeur. O objetivo, nesse caso, é apenas o de mapear alguns problemas considerados relevantes quando tratamos das relações entre história, memória, verdade e justiça, sem qualquer pretensão de solucioná-los.
\end{abstract}

Palavras-chave: KOSELLECK, Reinhart; Memória; Experiência.

\author{
Douglas Attila Marcelino \\ Doutor em História pela Universidade Federal do \\ Rio de Janeiro - UFRJ. Professor Adjunto II da \\ Universidade Federal de Minas Gerais - UFMG. \\ Brasil \\ douglasattila@gmail.com
}

\footnotetext{
Para citar este artigo:

MARCELINO, Douglas Attila. Experiências primárias e descontinuidades da recordação: notas a partir de um texto de Reinhart Koselleck. Revista Tempo e Argumento, Florianópolis, v. 8, n. 19, p. 338 - 373. set./dez. 2016.
}

DOI: $10.5965 / 2175180308192016338$

http://dx.doi.org/10.5965/2175180308192016338

${ }^{1}$ Esta pesquisa foi financiada pelo CNPq 


\title{
Primary experiences and discontinuities of memory: notes from a text by Reinhart Koselleck
}

\begin{abstract}
This article takes as its starting point a text by Reinhart Koselleck on the subject of memory, which examines supposed discontinuities between primary experiences and secondary forms of memory. Although this is a specific text and its statements are not intended to be understood as the foundation of a supposed thought-content unit of the author, it indicates some possible relationships with theses found in his other works. Then, some of his formulations are brought into a more strictly epistemological plane and compared with theses of authors such as Aleida Assmann, Joël Candau, Hannah Arendt, and Paul Ricoeur. The goal here is just to map some problems considered relevant when dealing with relationships among history, memory, truth, and justice, without any pretense to solve them.
\end{abstract}

Keywords: KOSELLECK, Reinhart; Memory;

Experience.

Em artigo recente sobre Reinhart Koselleck, Luciana Villas Bôas reproduziu um trecho de uma entrevista que o historiador alemão concedeu em 2005, em que buscava relacionar os eventos da Segunda Guerra Mundial e a decisão de tornar-se historiador. Na ocasião, Koselleck afirmou que todos aqueles que tiveram expectativas de vitória frustradas deveriam converter as razões da derrota em premissas metodológicas, conforme vinha acontecendo, pelo menos, desde Heródoto. Em seguida, acrescentou: “eu diria que completei meus estudos a partir da experiência da guerra. Minha atitude básica era o ceticismo como condição mínima para reduzir os excessos utópicos - mesmo os excessos utópicos de 1968" (VILLAS BÔAS, 2014, p. 95). Tal afirmação, não fosse bastante reveladora por si própria, parece condizente com teses diretamente presentes em seus textos. Em seu ensaio de natureza meta-histórica sobre as relações entre as 
formas de experiência e os métodos da história, de 1988, encontramos a seguinte frase: "no fato de ser um vencido reside um potencial inesgotável de conhecimento" (KOSELLECK, 2013a, p. 92). ${ }^{2}$ A afirmação, ao final do penúltimo parágrafo, assegurava o término enfático de um texto que, entre outros, concluía que as grandes inovações metodológicas da história advinham sempre do campo dos vencidos, não dos vencedores. 3

Embora os debates sobre o tema da memória e das experiências na Segunda Guerra ocupem um lugar específico na produção intelectual de Koselleck, as intervenções do historiador nesse plano têm sido menos discutidas do que seus estudos no âmbito da história dos conceitos (Begriffsgeschichte) e suas teses sobre a nova experiência do tempo inaugurada na modernidade. Um esforço de análise nesse sentido foi feito por Niklas Olsen, que utilizou textos, entrevistas e comunicações proferidas, sobretudo nos anos 1990, quando Koselleck participou mais ativamente do debate público sobre a elaboração de monumentos para a representação do Holocausto. Entendendo aquele como um momento em que o historiador alemão teria se tornado conhecido como um “clássico intelectual público”, expressando suas opiniões em assuntos de natureza social sem laços restritivos de natureza partidária, política ou ideológica, Olsen ressaltou que essa parte da obra de Koselleck era a de mais difícil compreensão, tendo em vista o suposto teor autorreferencial de certas discussões e o caráter ambivalente e hesitante de muitas afirmações (OLSEN, 2012). ${ }^{4}$

A perspectiva de Olsen, entretanto, era a de buscar uma organicidade no projeto intelectual de Koselleck abordando a integralidade de sua obra, conforme sintetizado na fórmula "história no plural", várias vezes repetida. Com objetivos muito mais restritos, este artigo partirá de um texto específico do historiador alemão, tendo em vista,

\footnotetext{
2 “En el hecho de ser un vencido reside un potencial inagotable de conocimiento" (tradução livre).

3 Niklas Olsen ressaltou a semelhança com a afirmação de Carl Schmitt de que as histórias extraordinárias eram escritas pelos vencidos, não pelos vencedores. O autor não deixou de indicar, entretanto, além da reconhecida importância da obra de Schmitt para o historiador alemão, características que singularizariam suas convicções, inclusive no que diz respeito à experiência da Segunda Guerra Mundial (OLSEN, 2012). A consulta do livro de Olsen foi feita no formato e-book e, por isso, evitaremos indicar as páginas das citações (que dependem da formatação escolhida).

${ }^{4} \mathrm{O}$ texto de Olsen é apenas um exemplo, tendo em vista a vasta bibliografia que tem se formado em torno da obra de Koselleck, que este artigo jamais pretenderia esgotar. Sobre o tema da memória e do culto dos mortos, podem-se destacar os importantes estudos feitos por Faustino Oncina (2011; 2009).
} 
inclusive, os riscos de sobrevalorizar continuidades e intencionalidades supostamente originadas ainda nos anos 1950 do século passado. O texto escolhido para nortear a análise foi um artigo sobre a descontinuidade da recordação produzido por Koselleck para um ciclo de conferências acerca do nacional-socialismo, organizado pelo Departamento de Filosofia da Universidade de Heidelberg, em 1998 (KOSELLECK, 2011a). ${ }^{5}$ Trata-se de uma intervenção intelectual marcada pela intensidade dos debates sobre o tema, cujas especificidades não devem ser negligenciadas, tanto pelas peculiaridades do assunto no caso alemão, quanto pelo risco de sobrevalorizar esse tipo de reflexão em relação a produções historiográficas mais elaboradas e sistemáticas. Por outro lado, além de ser possível encontrar certas afirmações semelhantes a outras presentes em análises consideradas mais relevantes na produção teórica de Koselleck, o texto pode servir para colocar em pauta temas de largo alcance acerca dos dilemas éticos e epistêmicos que caracterizam a historiografia.

Privilegiaremos aqui, portanto, reflexões sobre temas relativos aos fundamentos da verdade histórica e à relação entre memória, verdade e justiça. Confrontaremos algumas de suas proposições com as de autores que, embora não necessariamente relacionados à tradição intelectual de sua formação, são considerados relevantes para refletir sobre esses temas. Ressalte-se, nesse caso, que não se pretende conferir unidade às reflexões de Koselleck sobre o tema ou buscar as raízes de suas formulações (do ponto de vista biográfico ou da trajetória acadêmica), conforme já feito por muitos autores. Seu texto, marcado por uma atmosfera intelectual e política muito específica, servirá apenas de ponto de partida para a exploração teórica de problemas fundamentais quando tratamos do ofício do historiador. Nesse sentido, a confrontação de algumas de suas afirmativas com as reflexões de autores como Aleida Assmann, Joël Candau, Hannah Arendt e Paul Ricoeur não deverá ser compreendida como a busca de uma leitura correta, que solucione os problemas indicados, mas apenas como o esforço de exploração de aspectos relevantes que parecem condicionar a própria escrita da história.

\footnotetext{
5 O texto foi publicado na revista Deutsche Zeitschrift für Philosophie no ano seguinte. O momento era delicado, tendo em vista a exposição fotográfica Guerra de extermínio. Os crimes da Wehrmacht na Europa Oriental 1941-1944, organizada pelo Instituto de Investigação Social de Hamburgo, que retomava o ponto de vista de Goldhagen sobre a responsabilidade dos homens da Wehrmacht no Holocausto (ONCINA, 2007; GOLDHAGEN, 1999; FINKELSTEIN, 1999; HUSSON, 1997).
} 


\section{A experiência intransmissível: descontinuidade da recordação}

No artigo da conferência na Universidade de Heidelberg, Koselleck utilizou acontecimentos referentes ao seu passado como soldado alemão durante a Segunda Guerra Mundial para defender a tese de que o que caracterizaria a experiência era o fato de ser intransmissível (KOSELLECK, 2011a). Em forma de depoimento, o historiador relatava o aprisionamento dele e de mais trinta mil soldados alemães pelo exército russo, em 1945, indicando que, até então, nada sabiam acerca dos campos de concentração e do extermínio praticado pelo regime nazista. Forçados a caminhar até o campo de Birkenau, os soldados capturados entraram em contato com os relatos dos russos sobre as câmaras de gás que teriam ali funcionado. Os alemães, entretanto, não foram levados ao interior do campo e relutavam em acreditar naqueles fatos, até que uma experiência singular teria fornecido a Koselleck a certeza do ocorrido. Obrigado a descascar batatas junto aos demais prisioneiros, que estavam sob a vigilância de um polaco que havia sido detento de um dos campos, Koselleck teria resistido às ordens de mais rapidez argumentando que não teriam direito às batatas, que seriam dadas aos russos. Repentinamente, o polaco teria tomado em suas mãos uma cadeira e ameaçado golpear Koselleck: "quer que eu te rompa o crânio, vocês assassinaram milhões nas câmaras de gás", teria dito (KOSELLECK, 2011a, p. 40). ${ }^{6}$ Em seguida, a cadeira foi arremessada para um dos cantos da sala, num gesto igualmente espontâneo, que teria deixado no historiador alemão a certeza daquela revelação. Concluindo o relato, Koselleck argumentava que a experiência que teve naquele momento era intransmissível.

O pano de fundo da discussão de Koselleck sobre a experiência mencionada era o problema do conflito geracional entre os que vivenciaram mais diretamente a Segunda Guerra Mundial e a chamada "geração de 1968", tendo em vista, inclusive, as veementes acusações sobre intelectuais alemães acerca de supostos envolvimentos com o nacionalsocialismo. Para nossos objetivos, por outro lado, o importante é que, a partir da tese sobre a não transmissibilidade da experiência, Koselleck concluía pela radical descontinuidade entre experiências primárias e formas de recordação, esboçando uma formulação teórica que tenderia a ultrapassar os condicionantes específicos do seminário. Essa e outras ideias defendidas no texto não pareciam casuais e suas relações

\footnotetext{
6 “Quieres que te rompa el cráneo, vosotros habéis gaseado a millones” (tradução livre).
} 
com elementos presentes em outras de suas reflexões históricas não deveriam ser negligenciadas. É o caso de sua caracterização da "estrutura de experiência da geração que viveu em torno de 1945":

(...) na estrutura da experiência da geração que viveu em torno de 1945 estavam pressupostos modos segmentares de experiência, que se constituíam como espaços fragmentados ou com rachaduras em forma de prismas, nos quais as mais diferentes experiências se aglomeravam ou se rompiam, estando estas experiências em uma relação muito débil e precária com o acontecer geral de então, segundo a imagem que hoje temos dele. Isso também depende da unidade de gerações que têm suas experiências ao mesmo tempo, sem que eu tenha que partir de uma experiência coletiva. A tese de Durkheim me parece muito difícil de demonstrar empiricamente, pois toda experiência, como experiência primária, é experiência fracionada, segue sendo experiência segmentada, experiência intransferível e todos os posteriores processos de condensação são secundários. (KOSELLECK, 2011a, p. 40-41) ${ }^{7}$

A afirmação de Koselleck sobre a descontinuidade em relação à experiência primária se amparava em outras afirmativas igualmente relevantes, que também precisam ser consideradas com certo vagar: "é preciso que o espaço de experiência, que é fragmentado e plural, casual e intransferível, ultrapasse as experiências primárias para agregar-se num espaço de recordação constatado e institucionalizado, que seguirá sendo secundário" (KOSELLECK, 2011a, p. 41-42). ${ }^{8}$ Era por isso, argumentava Koselleck, que tinham sido criados o Departamento Universitário de História Contemporânea e numerosos institutos de história. Por outro lado, é certo que, na sua perspectiva, não se tratava de um processo especificamente relacionado com os acontecimentos do Terceiro Reich e da Segunda Guerra Mundial: "a passagem da experiência primária de origem plural e segmentar à recordação institucionalizada é um processo constante, que, em

7 “(...) en la estructura de la experiencia de la generación que vivió en torno a 1945 estaban presupuestos modos segmentarios de experiencia, que constituían espacios fragmentados o con roturas en forma de prismas, en los que las más diferentes experiencias se arracimaban o se quebraban, estando estas experiencias en una relación muy débil y precaria con el acontecer general de entonces, según la imagen que hoy tenemos de él. Esto también depende de la unidad de generaciones que tiene sus experiencias al mismo tiempo, sin que yo tenga por qué partir de una experiencia colectiva. La tesis de Durkheim me parece muy difícil de demostrar empíricamente, pues toda experiencia, como experiencia primaria, es experiencia quebrada, sigue siendo experiencia segmentada, experiencia intransferible y todos los posteriores procesos de condensación son secundarios" (tradução livre).

8 “(...) es necesario que el espacio de experiencia, que es fragmentario y pluralista, causal e intransferible, se remonte de las experiencias primarias para agregarse a un espacio de recuerdo constatado e institucionalizado, que seguirá siendo secundario" (tradução livre). 
cada atualidade, fixa cientificamente e ex post uma experiência" (KOSELLECK, 2011a, p. $42) \cdot 9$

Torna-se importante, de fato, tentar compreender as afirmações de Koselleck sobre a descontinuidade da recordação em relação à experiência considerando outros de seus textos, evitando uma leitura simplista das teses ali evidenciadas. Um primeiro aspecto a ressaltar, nesse caso, é que a pressuposição do caráter multifacetado e fragmentado das experiências de natureza primária, conforme implícito na citação feita anteriormente, não remetia apenas ao plano individual, tornando possível perceber a relevância que o recorte geracional apresentava quando consideramos outras formulações teóricas de Koselleck. ${ }^{10}$ Em seus escritos sobre os monumentos de culto aos mortos em batalhas na modernidade, que apontaram uma politização advinda da perda de força da interpretação cristã, Koselleck também considerou o recorte geracional fundamental à compreensão de uma sensibilidade social e política que, para além de acontecimentos mais imediatos, possuiria seu próprio ritmo de mudança temporal. ${ }^{11}$ Anterior às imposições relativas às regras próprias da linguagem das representações nos monumentos, essa sensibilidade guardaria forte marca geracional:

O culto político aos antigos monumentos aos mortos vai se esgotando na medida em que vão morrendo os sobreviventes de uma geração. É preciso remeter esse fato à mudança natural das gerações sem ter que tratar a questão do efêmero da modernidade. As experiências e as mensagens políticas são dificilmente transferíveis para além da morte. $O$

9 "El paso de la experiencia primaria de origen plural y segmentario al recuerdo institucionalizado es un proceso constante, que en cada actualidad fija científicamente y ex post una experiencia" (tradução livre).

10 A importância do recorte geracional pode ser vista em outros textos de Reinhart Koselleck, tendo, inclusive, papel relevante nas reflexões sobre as diferentes temporalidades que introduzem a coletânea Estratos do tempo (KOSELLECK, 2014).

${ }^{11}$ No texto, Koselleck mencionou "uma sensibilidade social e política que tem a sua própria história e que tem repercutido tanto produtiva como teoricamente sobre a linguagem dos monumentos" ["una sensibilidad social y política que tiene su propia historia y que ha repercutido tanto productiva como teóricamente sobre el lenguaje de los monumentos" (tradução livre)]. Para o autor, "a relação entre o imperativo político-social de sentido e sua configuração por meio de imagens foi produzida através da linguagem das formas dos monumentos, que deve chegar à sensibilidade do observador. Ambas, a forma e a sensibilidade, subjazem à mudança histórica, mas se modificam claramente em diferentes ritmos temporais" ["la relación entre el imperativo político-social de sentido y su configuración por medio de imágenes ha sido producida a través del lenguaje de las formas de los monumentos, que debe de llegar a la sensibilidad del observador. Ambas, la forma y la sensibilidad, subyacen al cambio histórico, pero se modifican claramente en variados ritmos temporales" (tradução livre)] (KOSELLECK, 2011b, p. 98-99). 
monumento que deve assegurar a transmissão de uma sensibilidade que vá além da morte não parece poder levar a cabo essa tarefa sozinho. (KOSELLECK, 2011b, p. 100) ${ }^{12}$

Se a tese da difícil transmissão de uma sensibilidade política para gerações subsequentes aparecia nesse texto ainda de 1979, voltado para o período que se estendia até o fim da Primeira Guerra Mundial, em trabalhos posteriores, o tema da ruptura relativa à Segunda Guerra foi retomado. Em texto publicado em 2002, por exemplo, Koselleck defendeu que a relação afirmativa, de natureza pedagógica, que existiria entre as causas da morte e suas finalidades políticas tendeu a ser substituída por representações indicativas de que o sentido já não mais poderia ser pressuposto ou encontrado. Na sua leitura, após eventos como as bombas de Hiroshima e Nagasaki, e, principalmente, o genocídio produzido pelo nacional-socialismo, as mensagens presentes nos monumentos remeteriam, sobretudo, à ausência de sentido, ao total desespero e ao caráter absurdo da morte violenta (KOSELLECK, 2011c, p. 117 ss.).

Não obstante esses textos sejam relevantes para o tema em pauta, talvez um dos mais importantes para a compreensão da complexa relação entre experiências primárias e recorte geracional seja sua reflexão de natureza meta-histórica sobre as formas de experiência e os métodos históricos. Publicado em 1988 e voltado para supostas constantes antropológicas que condicionariam as formas de aquisição e de relato das experiências humanas, o texto assume uma composição mais sistemática e parece indicativo da relevância do problema da geração no escopo das análises koselleckianas (KOSELLECK, 2013a). Para nossos propósitos, antes de explicarmos os elementos centrais de suas proposições meta-históricas, é fundamental compreender suas reflexões sobre as diferentes formas de aquisição da experiência e como se relacionam com o recorte geracional. Segundo Koselleck:

\footnotetext{
12 "El culto político a los antiguos monumentos a los caídos se va agotando a medida que van muriendo los supervivientes de una generación. Hay que remitir este hecho al cambio natural de las generaciones sin tener que tratar la cuestión de lo efímero de la modernidad. Las experiencias y los mensajes políticos son difícilmente trasladables más allá de la muerte. El monumento que debe asegurar la transmisión de una sensibilidad que vaya más allá de la muerte no parece poder llevar a cabo esta tarea solitario" (tradução livre).
} 
O espaço temporal mínimo da primeira aquisição da experiência se estende aos períodos que configuram a vida, a modificam ou estabilizam no itinerário que vai desde o nascimento até a morte, pois nenhuma experiência pode traduzir-se imediatamente. Quando pensamos no círculo de pessoas que são afetadas por tais estabilizadores das experiências a médio prazo, sempre são os homens individuais os afetados por ditas experiências. Mas cabe supor que os espaços de tempo das experiências são em grande medida específicos de uma geração. (KOSELLECK, 2013a, p. 51)

O trecho acima se refere a duas formas fundamentais de aquisição da experiência para Koselleck, relativas aos acontecimentos de curto e médio prazos, além de indicar que a noção de experiência não remetia apenas àquela diretamente vivenciada pelos sujeitos históricos no momento de sua efetivação, mas, igualmente, para sua acumulação dentro do espaço de tempo de uma vida ou geração. As experiências de curto prazo refletiriam justamente o caráter surpreendente de certos acontecimentos conforme vividos, sobretudo, individualmente (embora as surpresas possam ser coletivas), enquanto as experiências de média duração colocariam em pauta o recorte geracional:

As experiências são únicas, na medida em que são feitas, e repetíveis, na medida em que são acumuladas. Em consequência, toda história tem um duplo aspecto, que é constituído pela experiência e que é derivado dela. Tanto os acontecimentos singulares, surpreendentes, evocam experiências que dão lugar a histórias, como as experiências acumuladas ajudam a estruturar a médio prazo as histórias. Existem condições e processos específicos de uma geração nos quais as histórias pessoais se sobrepõem, mas que também remetem a espaços de tempo mais amplos, que configuram um espaço de experiência comum. Seja o que for "o espírito de uma época", é aqui que ele se encontra (...). (KOSELLECK, 2013a, p. 53)

13 "El espacio temporal mínimo de la primera adquisición de experiencia se extiende a los períodos que configuran la vida, la modifican o estabilizan en el itinerario que va desde el nacimiento hasta la muerte, pues ninguna experiencia puede traducirse inmediatamente. Cuando pensamos en el círculo de personas que son afectadas por tales estabilizaciones de las experiencias a medio plazo, siempre son los hombres individuales los afectados por dichas experiencias. Pero cabe suponer que los espacios de tiempo de las experiencias son en gran medida específicos de una generación" (tradução livre).

14 "Las experiencias son únicas - en la medida en que son hechas y repetibles - en la medida en que son acumuladas. En consecuencia, toda historia tiene un doble aspecto, que es constituido por la experiencia y que puede ser derivado dela. Tanto los acontecimientos singulares, sorprendentes, evocan experiencias que dan lugar a historias, como las experiencias acumuladas ayudan a estructurar a medio plazo las historias. Hay condiciones y procesos específicos de una generación en los que se solapan las historias personales, pero que también remiten a espacios de tiempo más amplios que configuran un espacio de experiencia común. Sea lo que sea 'el espíritu de una época', es aquí donde se encuentra (...)" (tradução livre). 
Como se pode notar, apesar da argumentação pela inexorabilidade da unicidade da experiência, Koselleck indicou que certa relação com a temporalidade permitiria configurar também experiências geracionais. Apesar da maneira distinta de processar os eventos devido a clivagens etárias e de posição social, "também é certo que os acontecimentos políticos evocam em todos algo minimamente comum, que ultrapassa diferenças de idade, de modo que se pode falar de unidades geracionais políticas para além da geração biológica e social" (KOSELLECK, 2013a, p. 51). ${ }^{15}$ É necessário, de fato, pensar num acúmulo de experiência impossível nos acontecimentos vivenciados em sua singularidade: “diferentemente das surpresas únicas que, por suposto, também podem afetar a muitos ao mesmo tempo, a confirmação e o fortalecimento das experiências remetem a experiências semelhantes dos contemporâneos (se não fosse assim não poderiam apenas ser acumuladas)" (KOSELLECK, 2013a, p. 51-52). ${ }^{16}$

Essas duas formas de vivência dos acontecimentos, com seus respectivos planos curto e médio de temporalidade, permitiriam, portanto, formular modos específicos de explicação para sua ocorrência, seja pela surpresa ou pela experiência acumulada geracionalmente. Mas, para além dessas duas formas de aquisição e explicação da experiência, existiria uma terceira, referente a uma mais longa duração, somente alcançável pela reflexão histórica. Dependente de técnicas de investigação que escapam à experiência imediata, essa forma de explicação corresponderia justamente à invenção do que Koselleck entenderia pelo método histórico: "a impossibilidade de recuperar o experimentado como único funda imediatamente a historiografia" (KOSELLECK, 2013a, p. 58). ${ }^{17}$ Trata-se, portanto, não apenas do que convencionamos chamar de método histórico, mas de uma forma determinada de explicação para as ocorrências dos fenômenos que, pautada na longa duração, permitiria falar de um modo específico de experiência: a "experiência histórica", entendida como forma de aquisição e explicação

15 “(...) también es cierto que los acontecimientos políticos evocan en todos algo común mínimo por encima de las diferencias de edad, de modo que se puede hablar de unidades generacionales políticas por encima de la generación biológica y social" (tradução livre).

16 "A diferencia de las sorpresas únicas que, por supuesto, también pueden afectar a muchos al mismo tiempo, la confirmación y el fortalecimiento de las experiencias remiten a experiencias semejantes de los contemporáneos (de no ser así no podrían apenas acumularse)" (tradução livre).

17 "La imposibilidad de recuperar lo experimentado como único funda inmediatamente la historiografía" (tradução livre). 
da experiência que guarda seus enraizamentos nas necessidades existenciais do homem de acumular e dar sentido aos eventos do mundo.

Inscrita na própria vida prática efetiva, a historiografia guarda relações com uma consciência histórica determinada acerca dos acontecimentos e sua temporalidade, que não é marca da escrita da história moderna, mas que, condicionando sempre qualquer esforço histórico de explicação, foi posta em evidência pelos historiadores da Antiguidade. A grande façanha de Heródoto e Tucídides, portanto, teria sido tomar essa condição existencial das formas de explicação e sua específica temporalidade como um pressuposto para a escrita e reescrita das histórias, configurando, sobretudo em Tucídides, uma primeira formulação mais sistemática do que entendemos pelo método histórico. Crescentemente formalizada, essa forma de explicação poderia se tornar autônoma em relação às suas condições de surgimento, o que, sem dúvida, traria ao texto de Koselleck uma singular pretensão e funcionalidade: de posse dos condicionantes antropológicos do método histórico, poderíamos, a partir de então, tratá-lo não como uma "evidência", mas discutir conscientemente sobre as formas mais produtivas de utilizá-lo. ${ }^{18}$

Com esse tipo de antropologia filosófica das condições de possibilidade da "experiência histórica" enquanto relato e vivência dos acontecimentos, Koselleck pretendia alcançar um nível de reflexão meta-histórico que, embora estruturante, não desconsiderasse o papel da contingência na história. Embora as experiências se acumulem, o condicionamento temporal da vida humana, seja no plano biológico da duração da existência ou no âmbito das unidades geracionais indicadas, traria consigo uma ruptura em relação ao sentido original das experiências, que apenas se acentuaria com a passagem do tempo. Enquanto construção racional de sentido, embora perpassada pelas três temporalidades já indicadas, a história remeteria, principalmente,

\footnotetext{
${ }^{18}$ Koselleck chegaria a afirmar que, "se investigarmos a história dos métodos aplicados ao longo do tempo até o método histórico-filológico, estes podem ser interpretados como desenvolvimentos das premissas antropológicas advertidas por Tucídides. (...) A diferença estabelecida por Tucídides entre linguagem e história, que ele mesmo havia tematizado expressamente mediante seus discursos, não é superável por nenhum método filológico" ["(...) si se rastra la historia de los métodos aplicados en el curso del tiempo hasta el método histórico-filológico, éstos pueden interpretarse como desarrollos de las premisas antropológicas advertidas por Tucídides. (...) La diferencia establecida por Tucídides entre lenguaje e historia, que él mismo había tematizado expresamente mediante sus discursos, no es superable por ningún método filológico"] (tradução livre) (KOSELLECK, 2013a, p. 73).
} 
parte da condição humana, apesar das tentativas metodologicamente fundamentadas de construção de explicações mais duradouras (KOSELLECK, 2006c). Resta saber se, ao fazêlo, Koselleck não apostou numa supervalorização do componente racional da historiografia como forma de relato da experiência caracterizado, sobretudo, pela explicação racional de mais longa duração. ${ }^{19}$ Pressupondo certa mudança geracional para que esse tipo de explicação fosse possível, sua distinção entre "subjetividade conjuntural" e "razões de longo alcance", além de trazer dificuldades para a chamada "história do tempo presente", não tenderia a subvalorizar o componente compreensivo que caracteriza a imaginação histórica? ${ }^{20}$ Retomaremos o tema mais adiante e, por ora, vale ressaltar que tal distinção recoloca em pauta a tese sobre a descontinuidade da recordação. Retornemos, então, ao texto do seminário de 1998.

\section{A descontinuidade da recordação no relato de Reinhart Koselleck}

As reflexões de Koselleck sobre a estrutura temporal da experiência, como indicado, recolocavam em primeiro plano uma descontinuidade entre "subjetividade conjuntural" e "razões de longo alcance", pressupondo certa ruptura entre as formas de aquisição da experiência relativas aos indivíduos e as unidades geracionais, por um lado, e aquelas referentes ao acúmulo de experiência a partir de reconstruções explicativas fundamentadas em elementos que ultrapassam os limites desses marcos temporais (da vida individual e da geração). Trata-se, em outros termos, da descontinuidade entre “experiências primárias”, marcadas pela "subjetividade conjuntural”, e reconstituições

19 A maior relevância concedida aos fenômenos que se repetem e à longa duração como fatores explicativos também pode ser percebida na avaliação de Koselleck acerca da história do tempo presente, cujo risco lhe parecia o de sobrevalorizar as novidades em relação aos fenômenos recorrentes (KOSELLECK, 2013C).

${ }^{20}$ Cabe destacar a análise de Elías Palti sobre as implicações da tentativa de Koselleck de retomar uma "crítica da razão histórica" solucionando-a em terreno kantiano e de forma contrária a Dilthey (PALTI, 2013; 2011). Uma leitura próxima à de Palti acerca dos fundamentos kantianos da proposta de Koselleck pode ser conferida em José L. Villacañas (2003). Uma crítica mais veemente pode ser encontrada em Sandro Chignola e Giuseppe Duso, contrários à tentativa de fundamentar uma ciência da história e favoráveis a uma completa identificação entre a história dos conceitos e a filosofia política (CHIGNOLA, 2003; 1998; DUSO, 1998). 
de experiência" conteria marcas de sensibilidade que nos permitiriam justamente entender o recorte geracional como fundamental, pois, como indicou Koselleck, caso contrário, jamais poderíamos acumular experiências de forma mais produtiva. Sua metahistória, portanto, repõe a tese sobre a descontinuidade da recordação. ${ }^{21}$ Mas, como pensar o relato de Reinhart Koselleck sobre a captura pelos russos em relação a estudos mais recentes sobre memória e narrativa?

Retomemos, portanto, o problema da transmissibilidade da experiência. Poderíamos considerar, por exemplo, certas reflexões de Paul Ricoeur, para quem "é somente ao nível da narrativa que se exerce primeiro o trabalho da lembrança" (RICOEUR, 2005, p. 37). As teses do filósofo francês repercutiriam em textos de vários autores, como nos de Fernando Catroga, que também compreenderia a memória como fenômeno relacional e intersubjetivo. Se os componentes cientificistas da sociologia de Halbwachs tornam ingênua certa propensão à reificação da "memória coletiva" como fenômeno exterior aos indivíduos, modelos mais relacionais de pensar a conformação da subjetividade permitiriam não apenas controlar essa hybris positivista, mas evitar uma perigosa tendência narcísica de encerramento na unicidade do eu (CATROGA, 2001, p. 19 Ss.). ${ }^{22}$ Sem dispensar totalmente Halbwachs, Catroga não deixaria de considerar a memória como uma formulação narrativa que, caracterizada pelos valores do presente, teria os pontos de partida e de chegada controlados pelo próprio evocador (CATROGA, 2001, p. 21).

O problema, por outro lado, foi tratado com maior especificidade por Aleida Assmann: "quando ocorre a verbalização, não nos lembramos mais dos acontecimentos em si, mas da nossa verbalização deles. Os signos linguísticos funcionam como nomes, com os quais objetos e situações podem ser evocados novamente" (ASSMANN, 2011, p. 286). Trata-se, portanto, da diferença entre transmissibilidade e comunicabilidade das

\footnotetext{
${ }^{21}$ Faustino Oncina defendeu que o interesse de Koselleck pela iconografia da morte violenta estava diretamente relacionado com sua meta-história (ONCINA, 2007, p. 57).

22 A diferença de perspectiva parece relacionada com o maior afastamento de Koselleck em relação à sociologia (conferir VILLACAÑAS, 2003).
} 
entendendo-a como a representação que o indivíduo produz sobre sua própria memória (CANDAU, 2011). Esse tipo de perspectiva parece discrepante da pressuposição de que experiências ocorridas em décadas anteriores poderiam permanecer como "experiências primárias", por sofrerem as alterações advindas da colocação em estruturas verbais de signos compartilhados.

Poderíamos nos interrogar, nesse caso, se uma certa descontinuidade não se produziria sempre em relação ao momento da própria vivência da experiência. É possível questionar também se formulações como as mencionadas acima estavam disponíveis nos horizontes do debate intelectual em que o relato de Koselleck foi produzido. A intenção aqui, entretanto, não é a de demonstrar, de modo anacrônico, supostas incorreções das teses do historiador alemão. Note-se que se trata de um autor complexo, que elaborou reflexões bastante sofisticadas sobre as relações entre experiência e linguagem, que permitiram, inclusive, o estabelecimento de uma leitura crítica da hermenêutica gadameriana por meio de sua diferenciação da teoria da história. Aliás, é importante notar que, em um dos textos mais indicativos de sua interpretação das formulações de Heidegger e Gadamer, Koselleck retomou o tema do recorte geracional como um dos fundamentos de sua reflexão meta-histórica, argumentando justamente pela existência de experiências específicas de cada geração, que seriam intransmissíveis (KOSELLECK, 1997, p. 248-250).23 O problema reaparecia, portanto, no momento em que Koselleck era colocado na situação singular de testemunha e historiador ao mesmo tempo, refletindo sobre a natureza de suas recordações e suas implicações do ponto de vista teórico. ${ }^{24}$

\footnotetext{
${ }^{23}$ Note-se que o texto "Teoria da história e hermenêutica" consiste em uma homenagem ao $85^{\circ}$. aniversário de Hans-Georg Gadamer, ocorrida em 18 de fevereiro de 1985. Trata-se, portanto, de uma produção muito anterior ao texto aqui analisado, de 1998.

${ }^{24} \mathrm{O}$ problema da relação entre os lugares do historiador e da testemunha tem sido objeto de uma enorme bibliografia, sobretudo depois da consolidação mais efetiva da chamada história do tempo presente. Uma reflexão mais específica sobre esse tema ultrapassaria muito os limites deste artigo, embora pudesse auxiliar na elaboração de outras interrogações acerca do texto de Reinhart Koselleck. Sobre o tema de modo mais geral, conferir, por exemplo, o já clássico trabalho de Annette Wieviorka, acerca do que chamou "a era da testemunha" (WIEVIORKA, 2006).
} 
Há dimensões do problema, por outro lado, que ultrapassam o tema da mediação linguística, aparecendo em outro texto de Koselleck, em que retoma o problema da memória da Segunda Guerra Mundial. Sem desconsiderar que os "esquemas da tradição linguística" imporiam novos conteúdos que se "sobrepõem ou eliminam o conteúdo original da experiência bélica", Koselleck ressaltou que "a isso se somam todas aquelas experiências que os indivíduos reuniram durante a guerra sem poder articulá-las linguisticamente e que seguem influenciando nos modos de pensar e nas maneiras de comportar-se, sem que a própria consciência deva ou possa dar razão a isso" (KOSELLECK, 2013b, p. 143). ${ }^{25}$ Tratando do mesmo problema, Candau retomou as reflexões de Maurice Bloch para indicar que "a presença do passado é bem mais complexa, bem menos explícita, mas também bem mais forte que a existência de narrativas explícitas nos poderia fazer crer”. A sutileza da tese a afasta da relação feita por Ricoeur entre lembrança e narrativa, pois "a parte da lembrança verbalizada não é a totalidade da lembrança" e o que não é manifestado diretamente por mediação linguística "tem significação social, pois se trata de um ativo colocado em reserva para futuras representações sociais" (CANDAU, 2011, p. 34). ${ }^{26}$

Novamente, o tema parece ter sido tratado de modo sensível por Aleida Assmann, em suas reflexões sobre o afeto como estabilizador das recordações (ASSMANN, 2011). Cabe considerar, nessa perspectiva, que o sentimento pode também ser um suporte da lembrança, talvez mais frágil justamente pela dificuldade de sua transmissibilidade. Nesse caso, inclusive, o problema seria não apenas o do meio a partir do qual o passado chega ao presente, mas também o de considerar que as marcas corporais deixadas pelos eventos e ações pretéritos afetam a própria estrutura de percepção dos indivíduos, reconfigurando sua subjetividade e, portanto, o modo como o mundo será valorado daí por diante. Estamos no limiar de tratar do tema do trauma como forma de estabilização da recordação, que interfere na própria matriz do inconsciente determinando compulsões, mas deixemos para voltar a esse assunto depois.

25 “(...) esquemas de traducción lingüística” /(...) "sobreponen o eliminan el contenido original de la experiencia bélica" /(...) "a ello se añaden todas aquellas experiencias que los individuos han reunido durante la guerra sin poderlas articular lingüísticamente y que siguen influyendo en los modos de pensar y las maneras de comportarse, sin que la propia consciencia deba o pueda dar razón de ello" (tradução livre). O texto foi publicado, originalmente, em 1992.

${ }^{26}$ Sobre as formas diversas de presença do passado no presente, conferir também a importante obra de David Lowenthal (LOWENTHAL, 1998). 
Partindo da leitura de Assmann, não haveria fundamento na busca da singularidade de uma experiência por meio das marcas de afetividade através das quais um acontecimento, depois de colocado em narrativa, teria mantido certa estabilidade da lembrança. Segundo a autora, isso só seria possível se considerássemos recordações produzidas num momento anterior a qualquer elaboração por meio de uma estrutura narrativa:

O afeto como potencializador da percepção conserva elementos da recordação que ingressam na memória de armazenamento como partes sem um todo ou como micronarrativas dobradas e lá ficam lado a lado, desconexas. Tais núcleos de recordação pré-linguística e protonarrativa estão no meio do caminho entre "impressão" e codificação simbólicas. $\mathrm{Na}$ direção da codificação simbólica, eles formam o material para processos secundários de estabilização narrativa e interpretativa. Aqui ainda é preciso retornar, mais uma vez, ao significado da verbalização de recordações. Transformam-se em anedotas as recordações que, via de regra, foram polidas regularmente por meio de um narrar. Nesse processo, a força estabilizadora migra do afeto para a fórmula linguística, de modo gradual. (ASSMANN, 2011, p. 282)27

De fato, a perspectiva de Assmann indica que, marcadas pelo afeto como principal suporte, determinadas lembranças migrariam progressivamente para a fórmula narrativa, tornando-se comunicáveis a partir da codificação linguística. Trata-se da passagem do afeto ao símbolo que, embora não seja vista como processo descontínuo, parece conter certa inexorabilidade quando tratamos de recordações que poderiam ser narradas, se chocando com a perspectiva de Koselleck de advogar qualquer permanência do sentido original de uma experiência ocorrida há mais de meio século. Não se deveria pensar numa lembrança de inúmeras verbalizações anteriores? Novas marcas deixadas na subjetividade individual por acontecimentos posteriores não causariam interferências não apenas no conteúdo, mas na sua própria estrutura perceptiva dos eventos, conformando uma miríade de graus diversos de descontinuidades? O problema mais importante aqui, entretanto, refere-se às implicações desse debate para pensarmos as especificidades dos critérios próprios à verdade histórica. Trataremos do tema adiante, após conjugarmos mais elementos a partir das reflexões de Koselleck sobre as descontinuidades da recordação.

\footnotetext{
27 Grifo no original.
} 


\title{
As três formas de descontinuidade da recordação ressaltadas por Koselleck
}

\begin{abstract}
Em definitivo, temos conhecido três formas diferentes de recordação, nenhuma das quais é satisfatória para explicar, julgar e refletir sobre o inconcebível e para poder enfrentar a recordação. A via científica, a moral e a religiosa levam, cada uma à sua maneira, ao desespero. $E$, precisamente é isto, o desespero, o que deve ser retido na recordação. Metaforicamente, cada passo leva junto à câmara de gás, mas não ao seu interior. (KOSELLECK, 2011a, p. 48) ${ }^{28}$
\end{abstract}

No artigo do seminário de 1998, logo após a afirmação acima, Koselleck passaria a fazer uma crítica às formas de representação do Holocausto nos monumentos alemães. Embora não explicitada, a sequência lógica da argumentação não deveria ser tomada como desprovida de significado: diante dos limites das vias científica, moral e religiosa então afirmados, a representação artística talvez contivesse relevantes singularidades. $\mathrm{E}$, nesse sentido, a veemência das afirmativas de que, "metaforicamente, cada passo leva junto à câmara de gás, mas não ao seu interior" e de que o que deveria ser retido na recordação é o desespero fornecem elementos importantes de análise. Partindo dessa ótica, poderíamos destacar que, enquanto a ciência, a moral e a religião podem levar até o desespero, somente a representação artística remeteria efetivamente para o sentido original da experiência, ou seja, o próprio desespero como experiência afetivamente vivenciada. Num autor cuja formação intelectual tem raízes numa tradição de fortes colorações neokantianas, essas frases ganham notórias singularidades, tendo em vista toda a riqueza da discussão sobre as especificidades relativas ao poder de afecção das imagens, possivelmente um dos elementos motivadores dos estudos de Koselleck sobre iconologia da morte violenta (conferir ONCINA, 2011).

Não parece sem propósito, nesse caso, que suas teses sobre os monumentos aos mortos tenham apontado para o ritmo próprio de alteração das sensibilidades sociais e políticas em relação aos eventos, o que remonta, entre outros, às reinvindicações de Jacob Burckhardt e Aby Warburg das imagens como plano anterior de contato com o

\footnotetext{
28 "En definitivo, hemos conocido tres formas diferentes de recuerdo, ninguna de las cuales es satisfactoria para explicar, juzgar y reflexionar suficientemente lo inconcebible y para poder afrontar el recuerdo. La vía científica, la moral y la religiosa llevan cada una a su manera a la desesperación. Y, precisamente es esto, la desesperación, lo que debe ser retenido en el recuerdo. Metafóricamente, cada paso lleva junto a la cámara de gas pero no a su interior" (tradução livre).
} 
permitiriam uma reativação energética da experiência passada, não discrepa das formulações koselleckianas. O potencial das imagens no sentido de fazer reviver sensações das mais profundas e extremas da experiência humana, tal como a incomensurável realidade genocidária perpetrada pelo nacional-socialismo, parece subjacente às suas argumentações sobre a necessidade de retenção do desespero.

Seria possível também traçar relações entre a pressuposição da existência de constantes antropológicas trans-históricas que marcou certos autores dessa tradição (como na busca de Panofsky pelas "tendências gerais e essenciais da mente humana" através das representações pictóricas) e as formulações meta-históricas de Reinhart Koselleck (PANOFSKY, 2012, p. 63 ss.). Sabendo da relação entre imagens e sonhos nos debates dessa tradição, por outro lado, torna-se relevante destacar que, em um dos ensaios de Futuro passado, Koselleck tomou como objeto de análise sonhos da época do Terceiro Reich coletados numa obra de Charlotte Beradt (KOSELLECK, 2006b). Entre as hipóteses formuladas, verifica-se justamente a concepção de que, como "retratos do interior da alma", os sonhos seriam histórias pré-linguísticas, que dariam acesso direto ao inconsciente e que, inclusive, guardariam certa unidade marcada pelo recorte geracional. Confrontando os sonhos dos indivíduos de fora e de dentro dos campos de concentração, Koselleck ressaltou que, diferentemente dos "sonhos utópicos" dos primeiros, saturados de experiências e deixando alguma margem para um espaço de ação imaginável, no caso dos segundos, haveria uma perda total da experiência, um desaparecimento da razão humana. "Vazios de ação e inundados de luzes e cores", esses sonhos seriam experiências de uma existência terrível e, assim, inapreensíveis e não comunicáveis. Estaríamos aqui, portanto, no plano das marcas corporais do terror, o que remete à possibilidade de representação diante da experiência do trauma.

Nesse caso, vale notar que a argumentação de Koselleck sobre os monumentos ao Holocausto se iniciava justamente colocando em pauta o problema do risco do esquecimento que a petrificação da experiência poderia gerar: "sempre que a recordação se materializa em um monumento não cabe menosprezar o perigo de que, precisamente 
porque fixa institucionalmente formas de recordação, bloqueie a própria lembrança" (KOSELLECK, 2011a, p. 48). ${ }^{29}$ O problema tornava-se particularmente grave por tratar-se de crimes supostamente incompreensíveis e inexplicáveis. Cabe lembrar que, numa perspectiva diferente, a crença na impossibilidade de qualquer representação chegou a configurar propostas perigosamente radicais: para François Lyotard, a única forma de manutenção duradoura de uma experiência não sintetizável como aquela seria evitar os monumentos, mantendo apenas o afeto como estabilizador da lembrança (um "afeto que não se sabe como classificar, como um estado de morte no meio da vida do espírito") (LYOTARD apud ASSMANN, 2011, p. 280). Essa espécie paradoxal de "doença sob prescrição" seria vigorosamente repelida por Aleida Assmann, para quem o excesso de afeto, insuportável como no trauma, se converteria não num estabilizador, mas num destruidor das recordações (ASSMANN, 2011, p. 281).

A possível concessão a uma maior capacidade da arte na busca pelo sentido original da experiência, como já indicado, se fundamentava na suposta descontinuidade que as vias científica, moral e religiosa, como formas de recordação, possuiriam em relação à experiência primária. A ênfase na ruptura em relação a esses modos supostamente institucionalizados de formatação das lembranças, e não em diversos graus de afastamento do sentido original inapreensível de qualquer experiência, teria implicações para essas três diferentes vias de acesso ao passado. No que concerne ao plano religioso, Koselleck apontou os limites tanto das tentativas de suportar o absurdo da dor por meio de penitências, como na oração cristã, quanto as tendências ao estabelecimento de cultos administrados pelo Estado, que fortaleceriam novas formas de "religião civil" tal como já se pretendia, pelo menos, desde Rousseau. No que compete à "resposta moral”, suas afirmações são realmente incisivas:

Mas a insistência na afirmação moral é uma afirmação repetida que só pode constatar: "foi injusto", "foi injusto", "foi injusto". Esta repetição não é um argumento que nos permita ganhar qualquer conhecimento adicional. Daí que a explicação moral se encontre numa situação aporética, pois, por um lado, não acrescenta conhecimento algum, mas, por outro, é necessária como contraste à pergunta sobre como pode

29 “(...) siempre que el recuerdo se materializa en un monumento no cabe menospreciar el peligro de que, precisamente porque fija institucionalmente formas de recuerdo, bloquee el propio recuerdo" (tradução livre). 
ocorrer. E, como se sabe, esta é a problemática de que trata Goldhagen, que a resolveu simplificadamente de um modo moral, mas que se pergunta com razão: como foi possível? A questão segue aberta e permanecerá em aberto, pois através da resposta moral fica somente quase explicada, mas nunca completamente, pois o âmbito moral e os âmbitos de explicação sociológicos ou de qualquer outro tipo científico são heterogêneos. Permanecem sendo heterogêneos e envolvem uma situação aporética: a de que o juízo moral é tão correto como inútil. É tão correto como inútil. (KOSELLECK, 2011a, p. 47) 30 $^{30}$

A repetição acerca da inutilidade do juízo moral parece indicativa da presença do tema para Koselleck. É importante destacar, por outro lado, que seria temerário descontextualizar sua discussão da complexidade conflitiva que envolvia o assunto no contexto específico do caso alemão naquele momento. O texto de Koselleck tratava de temas realmente espinhosos, estabelecendo afirmativas enfáticas de que "o juízo moral sempre tem razão" e de que se torna impossível tentar explicar os crimes sem que as perspectivas apresentadas sejam julgadas pela partilha ou não do ideário nazista: “do ponto de vista moral os crimes não são explicáveis, a menos que se diga 'eu o fiz'. Já dizendo 'eu não o fiz', surge a suspeita de que quem está falando está se desculpando" (KOSELLECK, 2011a, p. 43). ${ }^{31}$ Em sua concepção, esta lógica acusatória seria ineludível enquanto estivessem vivos aqueles que presenciaram o Terceiro Reich e o debate somente desapareceria depois de suas mortes: "enquanto viverem alemães que foram contemporâneos de Auschwitz, este argumento e esta explicação serão tomadas como desculpa, sem que se possa fazer nada contra isso" (KOSELLECK, 2011a, p. 43-44). ${ }^{32}$ Os rescaldos teóricos de um tema conflitivo do ponto de vista moral parecem evidentes, repercutindo em afirmativas que, apesar da sua aparente simplicidade, trazem em si uma

30 "Pero la insistencia en la afirmación moral es una afirmación repetida que sólo puede constatar: 'Fue injusto', 'fui injusto', 'fue injusto'. Esta repetición no es un argumento que nos permita ganar algún conocimiento adicional. De ahí que la explicación moral se halle en una situación aporética, pues por una parte no añade conocimiento alguno, pero, por otra, es necesaria como contraste a la pregunta de como pudo ocurrir. Y, como es sabido, esta es la problemática que trata Goldhagen, que ha resuelto Ilanamente de un modo moral, pero que formula justificadamente: ?como fue posible? La cuestión sigue abierta, y seguirá abierta, pues a través de la respuesta moral queda sólo cuasi explicada, pero nunca completamente pues el ámbito moral y los ámbitos da explicación sociológicos o de cualquier otro tipo científico son heterogéneos. Siguen siendo heterogéneos y entrañan una situación aporética: que el juicio moral es tan correcto como inútil. Es tan correcto como inútil" (tradução livre).

31 “(...) desde el punto de vista moral los crímenes no pueden explicarse, a menos que se diga 'yo lo hice'. Ya diciendo 'yo no lo hice', surge la sospecha de que quien habla se está disculpando" (tradução livre).

32 "Mientras vivan alemanes que fueron contemporáneos de Auschwitz, este argumento y esta explicación serán tomadas como disculpa, sin que se pueda hacer nada contra ello" (tradução livre). 
enorme complexidade e densidade, como na menção aos dilemas daqueles que, após atuação na SS, buscaram reintegrar-se à vida social. Ressaltando que "nem todo homem da SS era um assassino", Koselleck argumentava, por exemplo, que "esse era o problema: o cidadão normal era o que tinha praticado os crimes. Esta é a tese que Goldhagen sustenta parcialmente com razão" (KOSELLECK, 2011a, p. 45). ${ }^{33}$

É importante ressaltar que o problema do juízo moral envolve debates não apenas sobre os imperativos psicológicos dos próprios sujeitos que, tendo vivido a experiência extrema dos campos, precisariam reintegrar-se nos valores coletivos recompondo traços de intersubjetividade contra os riscos patológicos do isolamento, mas também o problema mais amplo da reconstituição do laço social, tendo em vista o reerguimento de uma esfera pública a partir, inclusive, do julgamento dos criminosos como forma de manutenção simbólica do contrato coletivo acerca do que é certo ou errado. A recomposição dos vínculos de confiança, o fortalecimento da crença nos valores formalizados por contratos legais (mesmo considerando a fragilidade característica dos contratos formulados por mãos humanas), entre outras questões semelhantes, envolvem esse amplo debate e vale ressaltar que, embora em uma passagem menos incisiva, Koselleck não deixou de afirmar a importância da esfera moral "para colocar na balança a responsabilidade dos envolvidos" (KOSELLECK, 2011a, p. 46). ${ }^{34}$

As afirmações de Koselleck podem ser também direcionadas para o campo epistemológico, tendo em vista que a pressuposição de uma não complementaridade entre os planos do conhecimento científico e do juízo moral, ou mesmo da inutilidade cognitiva deste último, permitem refletir sobre as especificidades da verdade histórica. Também no caso do discurso científico, para Koselleck, as limitações seriam significativas, gerando, inclusive, uma tensão excessiva sobre aqueles estudiosos que pretenderam explicar os eventos relacionados aos extermínios nazistas. O discurso científico parecia, de fato, uma "tarefa interminável", pois "aquilo que se deve explicar segue sendo incompreensível, seja do ponto de vista sociológico, da própria história social, da psicologia ou da crítica das ideologias, seja pela abordagem funcional ou intencional”

\footnotetext{
33 “(...) ese era el problema: el ciudadano normal era el que había llevado a cabo los crímenes. Esta es la tesis que Goldhagen sostiene parcialmente con razón” (tradução livre).

34 “(...) para poner en la balanza la responsabilidad de los implicados” (tradução livre).
} 
(KOSELLECK, 2011a, p. 46). ${ }^{35}$ Se confrontadas essas afirmativas com outras produzidas no mesmo período, elas adquirem um valor significativo, remetendo novamente ao problema da descontinuidade entre a experiência vivida e a explicação científica como uma das três formas de recordação já mencionadas.

\section{Sobre descontinuidades entre a ciência histórica e as experiências primárias}

Niklas Olsen reproduziu algumas afirmações elaboradas por Koselleck em eventos e textos diversos dos anos 1990, quando participou mais ativamente dos debates públicos sobre a memória do Holocausto. No texto relativo à comemoração do quinquagésimo aniversário do 8 de maio de 1945, por exemplo, o historiador alemão também trataria da permanência de certas experiências:

Há experiências que fluem dentro do corpo como lava incandescente e lá se petrificam. Irremovíveis, elas podem ser recuperadas a qualquer momento, sem alterações. Poucas dessas experiências podem ser transformadas em lembranças autênticas, mas, quando isso ocorre, elas estão baseadas em sua presença sensorial [sinnliche]. O cheiro, o gosto, 0 som, a sensação e a percepção ambiente, em suma, todos os sentidos, de prazer ou de dor, são despertados e não precisam de nenhum esforço de memória. (KOSELLECK apud OLSEN, 2012) $)^{36}$

A remissão a uma nova apreensão do ocorrido a partir de todos os sentidos, como indicada no trecho acima, repõe a tese da experiência primária como algo que permanece, irrompendo para além das intenções individuais e produzindo uma relação com o passado muito diferente daquela permitida pelas três formas de recordação antes indicadas. Mobilizando a integralidade dos sentidos, essa relação supostamente mais

35 “(...) tarea casi interminable"| “(...) aquello que hay que explicar sigue siendo incomprensible, ya sea desde el punto de vista sociológico, del propio de la historia social, de la psicología o de la crítica de las ideologías, ya sea desde el planteamiento funcional o el intencional” (tradução livre).

36 "There are experiences that flow into the body like red-hot lava and petrify there. Irremovable, they can be retrieved at any without changing. Few such experiences can be transformed into authentic memories; but when it happens, they are grounded in their sensorial [sinnliche] presence. The smell, the taste, the sound, the feeling and the visible surrounding, in short, all senses, in pleasure or pain, are awakened and need no effort of the memory" (tradução livre). O texto original, intitulado "Glühende Lava, zur Erinnerung geronnen", foi publicado no Frankfurter Allgemeine Zeitung no começo de maio de 1995. O dia 8 de maio de 1945 tornou-se data simbólica do fim da Segunda Guerra, devido à rendição da Alemanha, embora os conflitos, de modo geral, não tenham terminado nessa data. 
íntima com o passado, entretanto, estaria restrita a determinados acontecimentos vividos, já que nem todos deixariam traços duradouros. Ainda segundo Koselleck:

De fato, existem inúmeras lembranças que tenho frequentemente mencionado e repetido, mas cuja verdadeira presença sensorial (sinnliche Wahrheitspräsenz) desapareceu há muito tempo. Mesmo para mim, elas são apenas histórias literárias: quando ouço a mim mesmo, tudo o que posso fazer é acreditar nelas, mas eu já não posso atestar a sua basesensorial (sinnlichen) com certeza. No entanto, muitas coisas pertencem à experiência primária imutável, a lava petrificada. (KOSELLECK apud OLSEN, 2012) $)^{37}$

A contraposição mencionada por Koselleck entre "histórias literárias" e experiências cuja certeza poderia ser atestada por fontes sensoriais, assim como a pressuposição de uma experiência primária imutável, configuram problemas de difícil definição. Diferenciação semelhante, no texto sobre a descontinuidade da recordação, fundamentava a crítica aos excessos de juízos morais produzidos pela geração de 1968 em relação àqueles que teriam realmente vivido a intensidade da Segunda Guerra Mundial. Haveria um nível de experimentação do passado que, gerado pela experiência direta (tanto do ponto de vista individual como geracional), seria não apenas intransmissível, mas supostamente menos contaminado por julgamentos morais e ideológicos? É preciso avançar com vagar, sob o risco de supervalorizar determinadas teses presentes nesses textos específicos. De todo modo, torna-se relevante notar uma possível relação não apenas entre os trechos indicados e suas reflexões sobre os juízos morais pós-1968, mas também que pressuposições similares de descontinuidade ou ruptura estavam presentes no já mencionado ensaio meta-histórico sobre a metodologia da história e nos seus estudos sobre os monumentos aos mortos, que defendiam a existência de uma sensibilidade social e política dificilmente transmissível para além das gerações. ${ }^{38}$

\footnotetext{
37 "Indeed, there are numerous memories that I have often mentioned and repeated, but who's true sensorial presence [sinnliche Wahrheitspräsenz] has vanished long ago. Even for me, they are merely literary stories: when I listen to myself, all I can do is to believe in them, but I can no longer vouch for their sensory-based [sinnlichen] certainty. However, many things belong to the unchangeable primary experience, the petrified lava" (tradução livre).

${ }^{38}$ Refiro-me, por exemplo, aos textos "Monumentos a los caídos como lugares de fundación de la identidad de los supervivientes", de 1979, e "Cambio de experiencia y cambio de método. Un apunte históricoantropológico", de 1988, já analisados (KOSELLECK, 2011b; 2013a).
} 
Por outro lado, ao reivindicar a memória pessoal como um direito, Koselleck também parecia entender que esse nível de experiência primária, talvez por sua conformação pré-linguística e referida a componentes sensoriais, estaria menos sujeito às manipulações da memória coletiva:

Existe, portanto, um direito de veto da experiência pessoal que impede qualquer incorporação em uma memória coletiva. E é uma parte da frequentemente (e muitas vezes em vão) reivindicada dignidade humana, que todo ser humano tem direito a uma memória individual. Esse direito inteiramente pessoal a uma memória oferece proteção contra a doutrinação ideológica, contra o controle mental e a sujeição. (KOSELLECK apud OLSEN, 2012) 39

De fato, não se pretende fazer aqui um confronto entre essas afirmativas de Koselleck e sua obra de modo geral, devendo-se considerar, inclusive, que as aproximações mencionadas com outros de seus textos são fragmentárias. ${ }^{40}$ Conforme já indicado, torna-se mais importante para este artigo partir dessas formulações presentes em textos específicos não para reconstituir qualquer essência do pensamento de um historiador com obra tão extensa e diversificada, mas com o objetivo de problematizá-las à luz das teses de outros autores relevantes, que exploraram temas semelhantes em seus textos. Trazendo esses problemas para o plano epistemológico, por exemplo, podemos retomar algumas formulações de Aleida Assmann, particularmente no que diz respeito à diferenciação entre "verdade objetiva" e "veracidade subjetiva" ou, nos termos de Jean Starobinski, entre "verdade" e "autenticidade".

Ao tratar das dificuldades de Rousseau para lidar com as próprias recordações em suas Confissões, Starobinski referiu-se justamente à dimensão do afeto como uma forma de estabilização da memória cujos fundamentos epistemológicos são outros: "não posso

39 "There is therefore a veto-right of the personal experience that blocks for any incorporation in a collective memory. And it is a part of the often (and often vainly) claimed human dignity, that every human being has a right to an individual memory. Such an entirely personal right to a memory offers protection against ideological indoctrination, against mental control and subjection" (tradução livre). Intitulado "Gebrochene Erinnerung? Deutsche und polnische Vergangenheiten", o texto foi originalmente publicado em Das Jahrbuch der Deutschen Akademie für Sprache und Dichtung, em 2001.

40 Provavelmente por isso, Olsen optou por ressaltar as discrepâncias entre as teses de Koselleck sobre o tema da memória e aquelas presentes no restante de sua obra. Cabe ressaltar também que a análise aqui empreendida não busca compreender a perspectiva de Koselleck como cética quanto ao potencial explicativo da história, já que tal aspecto se chocaria com o grande investimento empírico de suas investigações sobre a modernidade. 

"verdade mais ampla, que foge, de fato, das leis da verificação". Nesse caso, portanto, "não nos encontramos mais no campo da verdade, das histórias verdadeiras; entramos, sim, no campo da autenticidade" (STAROBINSKI apud ASSMANN, 2011, p. 271)..$^{41}$ É nesse sentido que se pode compreender a discussão retomada por Assmann no momento seguinte do texto, sobre a "qualidade apodíctica das recordações afetivas": "elas são incorrigíveis, pois ficam de pé ou caem com a intensidade da referência vital, da impressão imediata. Quando se renuncia a estas últimas, não resta mais coisa alguma para si" (ASSMANN, 2011, p. 273).

O risco da pressuposição de uma verdade superior por meio da experiência direta, do ponto de vista filosófico, foi tratado por Hannah Arendt e, com o devido cuidado, pode ser aqui retomado com proveito para pensar a verdade histórica (ARENDT, 2008, p. 117 ss.). Trata-se de uma forma de pensar que, para Arendt, se tornou verdadeiro axioma de toda tradição metafísica ocidental, balizada numa suposta identidade entre o pensamento e as sensações por meio das quais conhecemos o mundo. Se, na tradição hebraica, a "metáfora-guia" da audição preencheu essa lacuna, no mundo ocidental os filósofos gregos teriam nos ensinado que a visão era a base da busca de uma verdade que, nessa leitura, somente poderia tornar-se inefável. A contrapartida inevitável, para Arendt, teria sido a desvalorização dos fundamentos dialógicos do ato de pensar, tendo em vista que as palavras por meio das quais os discursos se expressam poderiam, quando muito, orientar em direção à intuição, entendida como fundamento último de uma atividade valorizada por sua suposta natureza individual e contemplativa.

A preocupação de Arendt era a de defender que o pensamento filosófico se fundamentava na metáfora, recurso tomado como fonte de ligação entre o visível e o invisível, suprindo as limitações dos sentidos como partes de nossa experiência cognitiva do mundo, bases do senso comum. O recurso à metáfora, nesse ponto, visava justamente indicar a não equivalência entre o pensamento e os sentidos quaisquer que sejam, o que não pressupunha a desvalorização daqueles e, muito menos, uma recaída em

\footnotetext{
${ }^{41}$ Grifo no original.
} 
formulações derivativas da "falácia metafísica dos dois mundos", que tenderiam a adotar uma perspectiva dualista e irreconciliável entre estes dois planos: a metáfora, justamente, os interligaria, "dando-nos orientação quando tememos cambalear às cegas entre experiências nas quais nossos sentidos corporais, com sua relativa certeza de conhecimento, não nos podem guiar" (ARENDT, 2008, p. 129).

Talvez seja interessante, nesse sentido, pensar a noção de "verdade histórica" de forma aproximada àquilo que a autora concebeu como os reais alicerces do ato de pensar, tendo em vista sua natureza metafórica e discursiva, irredutível à tendência ao isolamento presente na atitude apenas contemplativa. Tomar a verdade da experiência como superior impede o estabelecimento de qualquer critério, pois a "verdade como autoevidência não demanda critério; ela é o critério, o árbitro final de tudo quanto possa vir" (ARENDT, 2008, p. 140). Diferentemente do "caráter essencialmente ativo, eu quase diria, violento, da intuição metafísica”, a "verdade histórica” (assim como o pensamento filosófico) parece demandar não apenas a palavra como forma de abertura ao outro, mas a exigência axiomática do não contraditório, da consistência argumentativa: "uma vez que o discurso é realizado em sequências de sentenças, o final do pensamento não pode jamais ser uma intuição, sem poder ser confirmado por algum pedaço de autoevidência observado através da contemplação muda" (ARENDT, 2008, p. 142-143).42

A reivindicação da incomensurabilidade da experiência, se pensada no plano epistêmico, pode correr o risco de aproximar-se da atitude contemplativa, cuja metáfora mais apropriada teria sido formulada por Heidegger: "o som ressonante do silêncio" (das Gelaüt der Stille) (Heidegger que, na leitura de Arendt, não teria escapado totalmente às metáforas da visão, tal como Walter Benjamin) (ARENDT, 2008, p. 143). O “ensimesmamento" da verdade tende a emudecer, tendo em vista que os sentidos são sempre individuais, fazendo com que a única atitude moralmente possível diante de uma reivindicação da verdade pela dor sofrida numa determinada experiência, por exemplo, seja o silêncio respeitoso. Até porque, conforme indicou Paul Ricoeur, a busca de justiça por meio da memória não poderia prescindir do axioma de que uma prioridade moral cabe às vítimas (RICOEUR, 2007, p. 102). A solução ricoeuriana apontava para o fato de

\footnotetext{
${ }^{42}$ No primeiro trecho, sobre o caráter violento da intuição metafísica, Hannah Arendt reproduz as palavras de Henri Bergson.
} 
que, nesse caso, as vítimas nunca deveriam ser nós mesmos, mas sempre outrem. ${ }^{43} \mathrm{O}$ problema da restauração da dignidade moral das vítimas é central no debate sobre memória e justiça, devendo ser acrescido ao da necessidade de recomposição da ordem pública de que tratamos anteriormente.

É interessante notar que a pressuposição da permanência das experiências primárias, tal como presente em determinados textos de Koselleck, guarda certas semelhanças com as teses de Henri Bergson sobre o funcionamento da memória, não apenas pela indissociabilidade dos momentos de percepção e de lembrança/reconhecimento, mas por fundamentar-se na possibilidade de acesso à integralidade das imagens do passado que ficariam conservadas em estado de latência (BERGSON, 1999). Para Paul Ricoeur, inclusive, o princípio estruturante de Matière et Mémoire, para além de toda complexidade do problema da duração, se fundamentaria numa antítese entre ação e representação, que associaria as lembranças integralmente conservadas ao plano da inconsciência (RICOEUR, 2007, p. 438 ss.). Foi esse tipo de concepção, assim como as bases metafísicas que conformaram as teses acerca da sobrevivência das imagens, que Ricoeur pretendeu rever, revalorizando a dimensão ativa do esforço de memória. ${ }^{44}$

Não seria difícil perceber relações entre os fundamentos metafísicos da noção contemplativa de verdade criticada por Arendt e a concepção de Bergson acerca do estado de latência das imagens, assim como as conexões evidentes desse debate com a valorização pela autora dos fundamentos ativos do pensamento filosófico. Não à toa, portanto, suas teses guardam alguma semelhança com a releitura de Matière et Mémoire proposta por Paul Ricoeur. Nesse caso, toda a discussão arendtiana sobre os fundamentos contemplativos da tradição metafísica ocidental repõe as teses que atravessam suas obras acerca do obscurecimento da política como campo de expressão da vida ativa, no qual a diversidade pode manifestar-se de forma libertária e configurar

\footnotetext{
43 “O dever de memória é o dever de fazer justiça, pela lembrança, a um outro que não a si” (RICOEUR, 2007, p. 101).

44 Consultar também sua discussão sobre os conceitos de "busca" e "evocação" que, referidos a obras clássicas de Platão e Aristóteles, funcionariam não como dicotomias, mas como polaridades, no mesmo sentido do raciocínio que estruturaria toda a parte sobre fenomenologia da memória do livro (RICOEUR, 2007, p. 45 ss.).
} 
aquilo que caracterizaria o essencialmente humano. ${ }^{45}$ Talvez esteja aqui uma possível diferença entre as concepções de Arendt e Koselleck no que diz respeito ao político, apesar de certa proximidade que caracteriza suas interpretações da modernidade. Isto porque, embora ambos tenham partido da pressuposição de que a diversidade é constitutiva das relações humanas, gerando interesses conflitantes, Koselleck não parece ter colocado o problema da política como o centro de sua Historik, se aproximando da concepção heideggeriana de valorização da temporalidade como tema fundamental, ainda que o tenha feito numa outra perspectiva. ${ }^{46}$

Trata-se, nesse caso, de um dos pontos mais relevantes quando pensamos nos elementos que distanciaram Hannah Arendt da filosofia de Heidegger, pois toda a ontologia fundamental enraizada no problema da revelação do ser foi praticamente substituída pelo tema do ocultamento da política, presente em praticamente toda a sua obra (DUARTE, 2003; ABENSOUR, 1989). A questão, porém, pode ser também pensada por relação ao modo como Reinhart Koselleck, em determinados textos, se apropriou do par conceitual amigo/inimigo estabelecido por Carl Schmitt, revalorizando a dimensão existencial da política ao entender esse conflito como dado antropológico estruturante do mundo histórico (KOSELLECK, 1997). 47 Nesse caso, talvez se possa diferenciar a percepção mais geral de que o político é um elemento constitutivo da vida humana daquela que, também o entendendo como fundamento irremediável da condição histórica do homem, o associaria à violência e sua inexorabilidade, como em Carl Schmitt (SCHMITT, 2015). Em Arendt, a categoria aparece, em geral, relacionada com o ideal da democracia como lugar de manifestação das diferenças.

\footnotetext{
$45 \mathrm{O}$ tema seria constante nas obras de Hannah Arendt, como, por exemplo, em A condição humana, Entre o passado e o futuro, Sobre a revolução, Sobre a violência, entre outros.

${ }^{46}$ O problema da presença do conceito de político de Carl Schmitt na obra de Koselleck e a fragilidade de pensar que o homem tem um acesso direto ao tempo histórico foi tratado por Villacañas (2003). As diferenças em relação à filosofia heideggeriana foram explicitadas em "Théorie de l'histoire et herméneutique" (KOSELLECK, 1997). Para uma comparação entre Koselleck e Arendt, consultar StefanLudwig Hoffmann (2010, p. 212-236).

47 Consultar também a referência a Carl Schmitt feita em Futuro passado (KOSELLECK, 2006a, p. 230-231).
} 
Memória pessoal ou justa memória?

Todo homem tem o direito de ter sua própria memória - que eu não vou permitir que seja coletivizada. (KOSELLECK apud OLSEN, 2012) ${ }^{48}$

A separação estabelecida por Koselleck entre experiências primárias e recordações secundárias remete também à reivindicação do direito de proteção às lembranças individuais contra possíveis deformações da memória coletiva. Tais afirmações podem, novamente, ser consideradas em relação àquelas de autores para os quais a ideologização da memória possuiria raízes em sua própria configuração narrativa (RICOEUR, 2007, p. 95-98). Nessa outra perspectiva, jamais haveria uma possível exterioridade quando se trata de memórias potencialmente narráveis, o que implicaria refletir sobre formulações específicas da noção de ideologia e suas relações com o plano da linguagem. O problema, por outro lado, pode ser também direcionado para o tema da relação entre verdade e justiça, que parece constitutivo da atividade de historiador.

Nesse caso, a separação estabelecida por Koselleck entre planos como o da moral e o científico se confrontaria com perspectivas também assumidas nos debates da época, que poderiam fazer lembrar as concepções de Ricoeur sobre o historiador como aquele que busca uma justa memória. No parágrafo final do texto aqui analisado, encontramos afirmações imperativas ressaltando que, em um monumento alemão sobre a Segunda Guerra:

(...) não podemos incluir nem excluir grupos concretos de vítimas. Não podemos fixar as fronteiras arbitrárias dos grupos que foram destinados à morte, estabelecendo uma hierarquia das vítimas. Porém, devemos lembrar que não é nossa competência erigir monumentos às vítimas (...). Um monumento dos assassinos que nos lembre quem tem a responsabilidade dos assassinatos, os extermínios e a morte nas câmeras de gás. Temos que aprender a viver com essa lembrança. (KOSELLECK, 2011a, p. 51) ${ }^{49}$

48 "Every man has the right to have his own memory - that I will not allow to be collectivized" (tradução livre). Trata-se de trecho de uma entrevista concedida por Koselleck em 2005, por conta do sexagésimo aniversário do 8 de maio de 1945, originalmente intitulada "Ich war weder Opfer noch befreit".

49 “(...) no podemos incluir ni excluir a grupos concretos de víctimas. No podemos fijar las fronteras arbitrarias de los grupos que fueron destinados a la muerte, estableciendo una jerarquía de las víctimas. Más bien debemos recordar que no es nuestra competencia erigir monumentos a las víctimas (...). Un monumento de los verdugos que nos recuerde quién tiene la responsabilidad de los asesinatos, los exterminios y el gaseado. Hemos de aprender a vivir con ese recuerdo" (tradução livre). 
As teses de Koselleck sobre os monumentos eram, inclusive, fundamentadas em dados empíricos fornecidos por importantes pesquisas historiográficas, indicando que a fronteira entre o uso do conhecimento científico e a elaboração de juízos morais sobre o passado pode ser mais tênue do que o próprio artigo sugere. Como entender essas formulações em relação à crítica anterior à inutilidade cognitiva dos juízos morais? A compreensão da moral, tal como aparece no texto do historiador alemão, parece próxima daquilo que Paul Ricoeur identificou como forma de julgamento típica do trabalho do juiz e não do historiador: o estabelecimento de uma sentença definitiva a partir de uma topologia imperiosamente binária, que, buscando a culpabilidade individual, concentra-se geralmente num pequeno número de atores. Tal fato se justificaria, em certa medida, pelas especificidades do caso em pauta, muito marcado pela atmosfera carregada de juízos morais que marcou os debates sobre o Holocausto na Alemanha. Nessa ótica, por outro lado, pouco se questionaria sobre a natureza coletiva ou as causas anteriores dos eventos, conforme se poderia pressupor numa tentativa de ampliação de perspectivas por meio da contextualização histórica (RICOEUR, 2007, p. 335-338).

Essas e outras características semelhantes foram ressaltadas por Ricoeur visando justamente desconstruir a identificação do trabalho do historiador com as prerrogativas morais do "dever de memória", mais próximo dos imperativos conjunturais de justiça que, exercendo-se de maneira coercitiva, impõem uma dívida que deveria ser sentida subjetivamente como obrigação. A tentativa de melhor equacionar o problema, revalorizando as discussões freudianas sobre o trabalho de memória e o trabalho de luto, entretanto, jamais prescindiu de certa identificação entre a busca da verdade e da justiça como centrais ao trabalho do historiador. Nesse caso, portanto, a relação entre conhecimento científico e juízo moral, que repõe em novos moldes as imbricações entre as dimensões veritativa e pragmática tanto da memória quanto da historiografia, parecem muito mais estreitas. ${ }^{50}$

A interpretação psicanalítica proposta por Ricoeur poderia estimular, inclusive, uma leitura da obra historiográfica de Koselleck como trabalho de luto: estaríamos diante

\footnotetext{
50 É nesse sentido que se pode compreender a discordância de Ricoeur em relação à alternativa estabelecida por Todorov entre a busca da verdade e do bem (RICOEUR, 2007, p. 99).
} 
de uma tentativa de reconciliação do historiador com seu passado como soldado do exército alemão? Isso porque o próprio Koselleck indicou a centralidade da experiência da Segunda Guerra Mundial para suas elaborações históricas, além de defender um direito de veto da memória individual que, para Olsen, seria sugestivo de uma atitude autoprotetora (OLSEN, 2012). Nesse caso, talvez devêssemos considerar que, diferentemente de Ricoeur, para quem a elaboração narrativa possuiria certa dimensão libertadora, Koselleck parecia entender que um risco menor do ponto de vista individual envolveria a manutenção de algumas experiências fora das deformações impostas pela linguagem. Tratar-se-ia da dificuldade de elaboração de determinadas experiências por meio de sua expressão narrativa?

Talvez fosse mais interessante conduzir a interrogação de modo inverso, perguntando por um possível uso da tensão gerada pela experiência do passado como estímulo para repensar o conhecimento histórico, como sugerido em suas afirmações acerca do potencial de inovação metodológica advindo da condição histórica de vencido. Nesse caso, o pessimismo reivindicado por Koselleck talvez estivesse relacionado com uma concepção atenta à inexorabilidade dos conflitos humanos, jamais solúveis pela perspectiva terapêutica adotada por Paul Ricoeur, com suas finalidades eminentemente curativas. Poderíamos falar, então, de tensões que, estimuladas a partir das relações subjetivas que o indivíduo mantém consigo mesmo, seriam as verdadeiras potencializadoras da imaginação histórica? Bastante discutíveis, essas especulações de teor psicanalítico parecem ter pouco alcance diante da solidez das obras historiográficas de Reinhart Koselleck, das quais o texto aqui selecionado para análise representa uma parte bastante limitada.

Talvez seja importante refletir mais sobre a possível relação entre a visão manifestada por Koselleck acerca dos limites dos julgamentos morais e sua inutibilidade cognitiva e sua concepção do mundo histórico como marcado por conflitos irredutíveis. ${ }^{51}$ Mas, nesse caso, qualquer contraposição com Ricoeur deve ser matizada, tendo em vista que as reflexões do filósofo francês sobre a memória não deixaram de ressaltar a persistência da violência e da guerra como aspectos fundamentais da história humana

${ }^{51}$ Conforme se poderia perceber na tentativa de ampliação da perspectiva heideggeriana a partir de um conjunto de pares conceituais ilustrativos desses elementos limitadores e contingentes típicos da condição histórica humana em Théorie de l'histoire et herméneutique (KOSELLECK, 1997). 
(RICOEUR, 2007, p. 92 ss.). Aliás, não se deveria esquecer que essa leitura ricoeuriana, diretamente inspirada na obra de Thomas Hobbes, é compatível com suas apropriações das teses freudianas, pelo menos se considerarmos a centralidade do pensamento hobbesiano no estudo sobre o mal-estar da cultura (FREUD, 2011, p. 57 ss.). Mas, esta obra de Freud, por outro lado, terminaria também num conflito irredutível, que discreparia de certo otimismo que atravessa as teses de Ricoeur sobre o potencial curativo de sua terapêutica pela conjugação entre o trabalho de memória e o trabalho de luto.

De fato, cabe perguntar se a tentativa ricoeuriana de conjugar um olhar atento aos conflitos irredutíveis do mundo humano com soluções terapêuticas não guardaria certas tensões com os próprios textos de Freud, menos pelo problema complexo da transposição de características relativas ao funcionamento da memória individual para o plano coletivo do que pela pressuposição do potencial do historiador como verdadeiro árbitro das faltas e excessos de memória. Se aceitarmos que o espaço público pode ser concebido como o equivalente da "arena" como região intermediária entre o psicanalista e o analisando, não podemos deixar de ressaltar que o próprio Freud colocou em questão quem estaria verdadeiramente autorizado para atuar nesse plano terapêutico num nível coletivo. ${ }^{22}$ Teria mesmo o historiador essa competência, ou mesmo essa autoridade dada pela coletividade para fazê-lo? E o uso terapêutico da memória poderia ter mesmo um potencial curativo ou a historiografia, como sugeriu Michel de Certeau, tenderia mais a ocultar os conflitos, apaziguando o presente por meio de uma relação com o passado (o outro) que jamais poderia solucionar as tensões irredutíveis que caracterizam a vida humana? (CERTEAU, 1975).

\footnotetext{
52 Sobre o espaço público como região intermediária entre terapeuta e paciente, ver A memória, a história, o esquecimento (RICOEUR, 2007, p. 92). Ao referir-se ao uso da psicanálise no tratamento de fenômenos culturais, Freud se interrogaria: "E no que diz respeito à aplicação da terapêutica da compreensão, de que adiantaria a mais pertinente análise da neurose social, se ninguém possui a autoridade para impor ao grupo a terapia?" (FREUD, 2011, p. 92).
} 


\section{Referências}

ABENSOUR, Miguel et ali (Ed.). Ontolotie et Politique: Actes du Colloque Hannah Arendt. Paris: Ed. Tierce, 1989.

ARENDT, Hannah. A vida do espírito. Rio de Janeiro: Civilização Brasileira, 2008.

ASSMANN, Aleida. Espaços da recordação. Campinas: UNICAMP, 2011.

BERGSON, Henri. Matière et mémoire. Paris: PUF, 1999.

CANDAU, Joël. Memória e identidade. São Paulo: Contexto, 2011.

CATROGA, Fernando. Memória, história e historiografia. Coimbra: Quarteto Editora, 2001.

CERTEAU, Michel de. L'écriture de l'histoire. Paris: Gallimard, 1975.

CHIGNOLA, Sandro. Historia de los conceptos, historia constitucional, filosofía política. Sobre el problema del léxico político moderno. Res publica, n. 11-12, p. 27-67, 200.

CHIGNOLA, Sandro. Historia de los conceptos e historiografía del discurso político. Res publica, n. 1, p. 7-33, 1998.

DUARTE, André. Hannah Arendt entre Heidegger e Benjamin: a crítica da tradição e a recuperação da origem da política. In: BIGNOTO, Newton; MORAES, Eduardo Jardim de (Orgs.). Hannah Arendt: diálogos, reflexões, memórias. Belo Horizonte: UFMG, 2003, p. 63-87.

DUSO, Giuseppe. Historia conceptual como filosofía política. Res publica, n. 1, p. 35-71, 1998.

FINKELSTEIN, Norman G. L'Allemagne en procès: la thèse de Goldhagen et la verité historique. Paris: Albin Michel, 1999.

FREUD, Sigmund. O mal-estar na civilização. São Paulo: P. Classics Cia das Letras, 2011.

GOLDHAGEN, Daniel J. Os carrascos voluntários de Hitler. Lisboa: Editorial Notícias, 1999.

HOFFMANN, Stefan-Ludwig. Koselleck, Arendt and the anthropology of historical experience. History and Theory, n. 49, p. 212-236, may 2010. 
HUSSON, Edouard. Une culpabilité ordinaire? Hitler, les allemands et la Shoah. Paris: François-Xavier de Guibert, 1997.

KOSELLECK, Reinhart. Cambio de experiencia y cambio de método. Un apunte históricoantropológico. In: KOSELLECK, Reinhart. Los estratos del tiempo. Barcelona: Paidós, 2013a, p. 43-92.

KOSELLECK, Reinhart. Las esclusas del recuerdo y los estratos de la experiencia. El influjo de las dos guerras mundiales sobre la conciencia social. In: KOSELLECK, Reinhart. Los estratos del tiempo. Barcelona: Paidós, 2013b, p. 135-154.

KOSELLECK, Reinhart. Continuidad y cambio en toda historia del tiempo presente. Observaciones histórico-conceptuales. In: KOSELLECK, Reinhart. Los estratos del tiempo. Barcelona: Paidós, 2013c, p. 115-133.

KOSELLECK, Reinhart. Futuro passado. Rio de Janeiro: Contraponto/PUC-Rio, 2006a.

KOSELLECK, Reinhart. Terror e sonho: anotações metodológicas para as experiências do tempo no Terceiro Reich. In: KOSELLECK, Reinhart. Futuro passado. Rio de Janeiro: Contraponto/PUC-Rio, 2006b, p. 247-265.

KOSELLECK, Reinhart. "Espaço de experiência” e "horizonte de expectativa”: duas categorias históricas. In: KOSELLECK, Reinhart. Futuro passado. Rio de Janeiro: Contraponto/PUC-Rio, 2006c, p. 305-327.

KOSELLECK, Reinhart. La descontinuidad del recuerdo. In: KOSELLECK, Reinhart. Modernidad, culto a la muerte y memoria nacional. Madri: Centro de Estudios Políticos y Constitucionales, 2011a, p. 39-51.

KOSELLECK, Reinhart. Monumentos a los caídos como lugares de fundación de la identidad de los supervivientes. In: KOSELLECK, Reinhart. Modernidad, culto a la muerte y memoria nacional. Madri: Centro de Estudios Políticos y Constitucionales, 2011b, p. 65101.

KOSELLECK, Reinhart. La transformación de los monumentos políticos a los caídos en el siglo XX. In: KOSELLECK, Reinhart. Modernidad, culto a la muerte y memoria nacional. Madri: Centro de Estudios Políticos y Constitucionales, 2011c, p. 103-128.

KOSELLECK, Reinhart. L'expérience de l'histoire. Paris: Seuil/Gallimard, 1997.

KOSELLECK, Reinhart. Los estratos del tiempo. Barcelona: Paidós, 2013. 
KOSELLECK, Reinhart. Estratos do tempo: estudos sobre a história. Rio de Janeiro: Contraponto/PUC-Rio, 2014.

KOSELLECK, Reinhart. Modernidad, culto a la muerte y memoria nacional. Madri: Centro de Estudios Políticos y Constitucionales, 2011.

KOSELLECK, Reinhart. Théorie de l'histoire et herméneutique. In: KOSELLECK, Reinhart. L'expérience de l'histoire. Paris: Seuil/Gallimard, 1997, p. 237-261.

KOSELLECK, Reinhart. Esbozos teóricos ¿Sigue teniendo utilidade la historia? Madrid: Escolar y Mayo Editores, 2013d.

KOSELLECK, Reinhart. The pratice of conceptual history: timing history, spacing concepts. Stanford: Stanford University Press, 2002.

KOSELLECK, Reinhart. Crítica e crise: uma contribuição à patogênese do mundo burguês. Rio de Janeiro: EDUERJ; Contraponto, 1999.

KOSELLECK, Reinhart. O conceito de história. Belo Horizonte: Autêntica, $2013 e$.

LOWENTHAL, David. Como conhecemos o passado. Projeto História, São Paulo, n. 17, 1998.

OLSEN, Niklas. History in the plural. Nova Iorque; Oxford: Berghahn Books, 2012 (e-book).

ONCINA, Faustino. Introducción. In: KOSELLECK, Reinhart. Modernidad, culto a la muerte y memoria nacional. Madri: Centro de Estudios Políticos y Constitucionales, 2011, p. IXLXV.

ONCINA, Faustino. Historia conceptual, ilustración y modernidad. México: Anthropos Editorial, 2009.

ONCINA, Faustino. Necrológica del Outsider Reinhart Koselleck: el 'historiador pensante' y las polémicas de los historiadores. Isegoría, n. 37, p. 35-61, 2007.

PALTI, Elías José. Ideas, conceptos, metáforas. La tradición alemana de historia intelectual y el complejo entramado del lenguaje. Res publica, n. 25, p. 227-248, 2011.

PALTI, Elías José. Introducción. In: KOSELLECK, Reinhart. Los estratos del tiempo. Barcelona: Paidós, 2013, p. 9-32.

PANOFKSY, Erwin. Significado nas artes visuais. São Paulo: Perspectiva, 2012. 
RICOEUR, Paul. O perdão pode curar? In: HENRIQUES, Fernanda. (Org.). Paul Ricoeur e a simbólica do mal. Porto: Edições Afrontamento, 2005, p. 35-40.

SCHMITT, Carl. O conceito de político. Lisboa: Edições 70, 2015.

VILLACAÑAS, José Luis. Histórica, historia social e historia de los conceptos políticos. Res publica, n.11-12, p. 69-94, 2003.

VILLAS BÔAS, Luciana. Reinhart Koselleck (1923-2006). In: PARADA, Mauricio. (Org.). Os historiadores: clássicos da história. Petrópolis: Vozes; Rio de Janeiro: PUC-Rio, 2014, p. 93-116.

WIEVIORKA, Annette. The era of the witness. Ithaca: Cornell University Press, 2006.

Recebido em 12/06/2016 Aprovado em 25/10/2016 